\title{
PATHOTYPE DIVERSITY OF Pyricularia grisea FROM IMPROVED UPLAND RICE CULTIVARS IN EXPERIMENTAL PLOTS
}

\author{
ANNE S. PRABHU ${ }^{1}$, MARTA C. FILIPPI ${ }^{1} \&$ LEILA G. ARAUJO ${ }^{2 *}$ \\ ${ }^{1}$ Embrapa Arroz e Feijão, Cx. Postal 179, CEP 75375-000, Santo Antônio de Goiás, GO, Brazil, Fax (062) 533-2172, \\ e-mail: prabhu@cnpaf.embrapa.br; ${ }^{2}$ Escola de Agronomia, Universidade Federal de Goiás, Cx. Postal 131, \\ CEP 74001-970, Goiânia, GO, e-mail: leilag@cnpaf.embrapa.br
}

(Accepted for publication 12/08/2002)

Corresponding author: Anne Sitarama Prabhu

PRABHU, A.S., FILIPPI, M.C. \& ARAÚJO, L.G. Pathotype diversity of Pyricularia grisea from improved upland rice cultivars in experimental plots. Fitopatologia Brasileira 27:468-473. 2002.

\begin{abstract}
A study was undertaken to examine the pathogenic diversity of Pyricularia grisea isolates retrieved from 14 upland rice (Oryza sativa) cultivars in experimental plots during a period of five years. Inoculations were performed on 32 genotypes with 85 monoconidial isolates under controlled greenhouse conditions. Based on the reaction pattern of eight international differentials, eleven pathotypes of $P$. grisea were identified. The predominant international races or pathotypes were IB-9 (56.4\%), IB-1 (16.4\%) and IB-41 (11.8\%). A set of eight commercial upland rice cultivars ('Carajás', 'Confiança', 'Maravilha', 'Primavera', 'Progresso', 'Caiapó', 'IAC-47', 'IAC201') was utilized as additional differentials for describing the virulence pattern of $P$. grisea. Twenty-six Brazilian pathotypes were identified on the basis of disease reaction on these differentials, in contrast to the 11 international pathotypes. The most predominant

Brazilian pathotypes, BB-21 and BB- 41 were represented by $28.2 \%$ and $17.6 \%$ of the isolates tested, respectively. Isolates virulent and avirulent to cultivar 'Primavera' were encountered within the pathotype IB-1. Utilizing Brazilian cultivars as differentials, the 14 isolates of the pathotype IB-1could be further classified into eight local pathotypes, BB-41, BB-13, BB-21, BB-9, BB-29, BB-61, BD-9 and BG-1. Virulence to improved rice cultivars 'Canastra', 'Confiança', 'Carisma', 'Maravilha', 'Primavera' and 'Bonança' was frequent in pathogen population. Some of the Brazilian pathotypes that showed differential reaction on commercial rice cultivars could be utilized for incorporating resistance genes in susceptible cultivars improved for grain quality, by conventional breeding methods.

Additional key words: Oryza sativa, Magnaporthe grisea, physiologic races, differential varieties, resistance, virulence.

\section{RESUMO \\ Diversidade de patótipos de Pyricularia grisea provenientes de cultivares de arroz de terras altas em parcelas experimentais}

Foi estudada a diversidade patogênica de isolados de Pyricularia grisea coletados de 14 cultivares de arroz (Oryza sativa) de terras altas, em campos experimentais durante um período de cinco anos no Brasil. Foram realizadas inoculações em 32 genótipos com 85 isolados monospóricos em condições de casa de vegetação. Com base nas reações das oito diferenciadoras internacionais, onze patótipos de $P$. grisea foram identificados. Os patótipos internacionais predominantes foram IB-9 (56.4\%), IB-1 (16.4\%) e IB-41 (11.8\%). Oito cultivares locais ('Carajás', 'Confiança', 'Maravilha', 'Primavera', 'Progresso', 'Caiapó', 'IAC-47' e 'IAC-201') foram utilizadas como diferenciadoras para descrever o padrão de virulência de isolados de $P$. grisea. Foram identificados 26 patótipos locais com base no tipo de reação nestas diferenciadoras, em contraste com os

11 patótipos internacionais. Os patótipos brasileiros mais predominantes, BB-21 e BB-41, representaram $28,2 \%$ e $17,6 \%$, dos isolados testados, respectivamente. Isolados virulentos e avirulentos com a cultivar 'Primavera' foram encontrados dentro do patótipo IB1. Os 14 isolados do patótipo IB-1 foram subdivididos em oito patótipos locais, BB-41, BB-13, BB-21, BB-9, BB-29, BB-61, BD-9 e BG-1. A virulência para as cultivares melhoradas como 'Canastra', 'Confiança', 'Carisma', 'Maravilha', 'Primavera' e 'Bonança' foi freqüente na população do patógeno. Alguns patótipos brasileiros que apresentaram reações diferenciais em cultivares comerciais poderão ser utilizados para incorporação de genes de resistência nas cultivares suscetíveis melhoradas para qualidade de grãos pelo método de melhoramento convencional.
\end{abstract}

\section{INTRODUCTION}

Rice blast caused by Pyricularia grisea (Cooke) Saccardo $=P$. oryzae Cavara [Tel.: Magnaporthe grisea (Hebert) Barr.] continues to be one of the major rice (Oryza

*Bolsista do CNPq sativa) diseases in different parts of the world including Brazil, in spite of the extensive research efforts on breeding varieties for blast resistance, over the years. The disease assumes greater dimension in yield losses under upland conditions in the west central and northern states of Brazil. Embrapa Rice \& Beans in collaboration with other state research organizations has developed several upland rice cultivars with superior grain 
Pathotype diversity of Pyricularia grisea from improved upland rice cultivars...

quality and different degrees of blast resistance for cultivation. Blast epidemics have been reported to be of common occurrence in the newly released cultivars such as 'Primavera', 'Maravilha' and 'Confiança' during the past three years. The limited durability of blast resistance of the improved rice cultivars could be attributed to the highly complex and variable nature of the pathogen. The blast fungus has been known to be composed of races or pathotypes (Latterell et al., 1954).

Latterell et al. (1954) first reported the occurrence of pathogenic races in $P$. grisea in the USA. Since then several races have been reported in different countries using different rice cultivars as differentials. The number of races has increased as more isolates were tested (Ou, 1980). An international set of eight cultivars was selected for identifying races of $P$. grisea on the basis of reaction on these differentials. These races were called international races and were designated as IA, to $\mathrm{IH}$, followed by numerals to indicate race numbers (Atkins et al., 1967; Ling \& Ou, 1969). International races representing all nine groups of races were recovered from 15 rice cultivars in Colombia (Correa-Victoria \& Zeigler, 1993; Levy et al., 1993). In Brazil, the occurrence of physiologic races has been reported by several investigators (Amaral et al., 1979; Bedendo et al., 1979; Ribeiro, 1980; Ribeiro \& Terres, 1987; Prabhu \& Filippi, 1989; Urashima \& Isogawa, 1990; Malavolta et al., 1992; Filippi et al., 1999).

In Japan, a set of nine differentials, each with a known resistance gene, was proposed (Yamada et al., 1976). Since these differentials are not isogenic lines, other unknown resistance genes may be present in cultivars that caused a failure to describe adequately the pathotype diversity in the tropics (Ou, 1980). Recently, Mackill \& Bonman (1992) developed an improved differential set of five near isogenic lines (NIL's) of cultivar CO39, with single major blast resistance genes, for characterizing pathogen population. However, their value became limited because only a few known genes are involved to describe the entire virulence spectrum of pathotypes.

In a study utilizing International, Japanese and Korean differential sets, Bonman et al. (1986) have shown that none of the agriculturally important Philippine isolates of $P$. grisea could be differentiated. The conventional differential sets and the expression of results as race numbers did not yield useful information. According to these authors, for practical purpose in studies on the diversity of agriculturally important isolates of $P$. grisea, the use of widely grown local commercial cultivars a differential set is preferable to the conventional set of eight international differentials. Detailed investigations on pathogenic variability of $P$. grisea at the Santa Rosa breeding site in Colombia have also shown that several races could be further differentiated into different pathotypes when local commercial cultivars were used as differentials (CorreaVictoria \& Zeigler, 1993).

The knowledge on the pathotypes of $P$. grisea that affect the rice cultivars in the experimental plots under field conditions in Brazil is important for resistance breeding. The present paper reports the pathotypic diversity among the isolates retrieved from improved upland rice cultivars under natural conditions of infection in field plots, the cultivar differences in relation to the pathotypes that affect them and virulence characterization of Brazilian pathogen population of $P$. grisea using an additional set of eight local upland rice cultivars as differentials.

\section{MATERIALS AND METHODS}

Single conidial isolates of $P$. grisea were obtained from sporulating lesions on leaves of 13 improved upland rice cultivars ('Primavera', 'Maravilha', 'Canastra', 'Caiapó', 'Carajás', 'Progresso', 'Rio Paranaíba', 'Araguaia', 'Guarani', 'IAC-201', 'Bonança' and 'Carisma'). Collections were made in experimental plots located in the Embrapa Rice and Beans, Goiânia, during five consecutive years (1996-2000).

Five hundred and twenty isolates were established and from them, 85 were selected for evaluation according to the year and cultivar from which they were retrieved. The virulence frequency of the selected isolates was tested under controlled greenhouse conditions, utilizing 32 genotypes including 14 upland rice cultivars ('Araguaia', 'Bonança', 'Caiapó', 'Canastra', 'Carajás', 'Carisma', 'Confiança', 'Guarani', 'IAC-47', 'IAC-201', 'Maravilha', 'Primavera', 'Progresso' and 'Rio Paranaíba'), a check for partial resistance evaluation ('Moroberekan'), a somaclone of cultivar 'Araguaia' (SC09) with a known gene for vertical resistance, besides eight standard international differentials ('Dular', 'Kanto 51', 'NP125', 'Raminad Str 3', 'Usen', 'Zenith', 'Caloro' and 'Sha-tiao-tsao'), five near isogenic lines of ' $\mathrm{CO}$ 39' ('C 101 LAC', 'C101A 51', 'C104 PKT', 'C101 PKT' and 'C101-TTP-4L-23'), a recently released improved upland rice cultivar ('Aimoré'), and two introduced lines of Oryza glaberrima Steud (OG 217 and OG 218). The test material was planted in plastic trays $(15 \times 30 \mathrm{~cm})$ containing $3 \mathrm{~kg}$ of soil fertilized with NPK (5 g of 5-30-15 $+\mathrm{Zn}$ and $3 \mathrm{~g}$ of ammonium sulfate per $3 \mathrm{~kg}$ of soil). Thirty two cultivars, 16 per tray, were sown (ten to 12 seeds/cultivar) in $5 \mathrm{~cm}$ long rows.

The inoculation procedure described earlier by Filippi et al. (1999) was utilized. The physiologic races were identified based on the reaction of eight standard international differentials (Atkins et al., 1967; Ling \& Ou, 1969). Leaf blast reaction was assessed seven to nine days after inoculation taking into consideration only two types of reaction of the host, compatible or susceptible and incompatible or resistant reaction, according to Ling \& Ou (1969). The infection types 0 to 3 were considered as resistant and 4 to 9 as susceptible in the disease evaluation scale of 0-9 (International Rice Research Institute, 1988). In case of ambiguous or intermediate reaction, inoculation tests were repeated whenever necessary and the ones that gave consistent and uniform reaction were utilized for analysis. A tray containing international and Brazilian differential cultivars as a noninoculated control was maintained to ensure that no contamination occurred during the inoculation procedure 


\section{RESULTS AND DISCUSSION}

The Brazilian pathotypes were differentiated on the basis of reaction in eight commercial upland rice cultivars. They were selected taking into consideration the virulence frequency of the isolates, genetic base, and agricultural importance. Care was taken to avoid cultivars with 'IAC-47' as one of the parents such as 'Rio Paranaiba', 'Guarani', 'Cuiabana', etc. The selected eight cultivars, henceforth, can be used as standard set of differentials for identifying Brazilian pathotypes of $P$. grisea collected from upland rice cultivars. The international differentials were substituted (Table 1).

The Brazilian pathotypes were prefixed by the letter "B" instead of "I". The groups were designated as BA, BB, $\mathrm{BC}, \mathrm{BD}, \mathrm{BE}, \mathrm{BF}, \mathrm{BG}, \mathrm{BH}$ and $\mathrm{BI}$. The isolates of $P$. grisea virulent to 'Carajás' belong to $\mathrm{BA}$ group (128 reaction patterns) similar to the international race group IA. This group separation was based on susceptible reaction of the international rice differential 'Raminad Str.3' (Atkins et al., 1967). The isolates, which induced susceptible reaction on the second differential 'Zenith' and resistant reaction on 'Raminad Str' were grouped under IB group. In a similar manner the isolates showing susceptible reaction on second Brazilian differential 'Primavera' pertain to BB group (64 reaction patterns). The isolates with susceptible reaction on 'Maravilha' but resistant reaction on 'Carajás' and 'Primavera' were designated as BC group ( 32 patterns). The isolates causing susceptible reaction on 'Confiança', 'Progresso', 'Caiapó', 'IAC-47' and 'IAC-201' but resistant reaction to the first three differentials taken in a sequential order, were designated as $\mathrm{BD}, \mathrm{BE}, \mathrm{BF}, \mathrm{BG}, \mathrm{BH}$ groups with $16,8,4,2$, and 1 reaction patterns, respectively. The race group BI was proposed for the isolates which show resistant reaction on all eight differentials as in the case of international race group II. The numeral following the group letters indicates the pathotype number similar to the numbering of international races and the same key with reaction patterns of international differentials (Ling \& Ou, 1969) was used for designating Brazilian pathotypes.
Based on the reaction pattern of eight international differentials, 11 pathotypes (IB-1, IB-9, IB-41, IB-45, IB-33, IB-37, IC-1, IC-9, IC-25, ID-9, and IG-1) were identified in a sample population of $85 \mathrm{P}$. grisea isolates collected from 14 upland rice cultivars (Table 2). The predominant international races or pathotypes were IB-9 (56.4\%), IB-1 (16.4\%) and IB-41 (11.8\%). The pathotype IB-9 was recovered from all 14 rice cultivars. All seven isolates of $P$. grisea collected from the cultivar 'Rio Paranaiba' during a four-year period from 1997 to 2000 was classified as the pathotype IB-9. The pathotypes IB-1, IB-41 and IB-45 were recovered from eight, seven and three of the 14 rice cultivars, respectively. The predominance of the pathotypes IB-9, IB-1 and IB-41 was also reported in tests conducted during 1986-88, among isolates retrieved from ten upland rice cultivars (Prabhu \& Filippi, 1989). These results showed that there was no change in relation to the frequency of the predominant pathotypes despite the change in varietal pattern. The three pathotypes representing group IC, two of IC-9, and one each of IC-1 and IC-25 obtained from 'Primavera' were in low frequency.

Twenty-six Brazilian pathotypes were identified utilizing eight commercial upland rice cultivars in contrast to 11 international pathotypes (Table 2). They represented race groups $\mathrm{BB}, \mathrm{BA}, \mathrm{BC}, \mathrm{BD}, \mathrm{BG}, \mathrm{BF}$ and $\mathrm{BI}$. The most predominant Brazilian pathotypes BB-21 and BB-41 were represented by $28.2 \%$ and $17.6 \%$, respectively of the 85 test isolates. A relatively high frequency of pathotype BB-21 was obtained from 'IAC-47', 'Canastra' and 'Bonança'. All isolates recovered from 'Bonança' were classified as BB-21 whereas with international differentials two pathotypes IB-9 and IB-33 were identified. Similarly, all isolates collected from 'Rio Paranaiba' were classified as the pathotype IB-9 but with the Brazilian differentials it was subdivided into four different pathotypes such as BB-41, BB-49, BC-1 and BD-9.Twenty-four of the 28 pathotypes were not very frequent and were recovered at random from different cultivars. The utility of the pathotypes of $P$. grisea is enhanced if the designation indicates both international and Brazilian groups followed by its respective number. For example, pathotype of

\begin{tabular}{lccl} 
TABLE & $\begin{array}{c}\text { - Pathotype group of Pyricularia } \\
\text { differentials and their parents }\end{array}$ & \\
\hline \hline $\begin{array}{l}\text { Pathotype } \\
\text { group }^{1}\end{array}$ & $\begin{array}{c}\text { International } \\
\text { differentials }\end{array}$ & $\begin{array}{c}\text { Brazilian } \\
\text { differentials }\end{array}$ & \multicolumn{1}{c}{ Parents of Brazilian differentials } \\
\hline A & Raminad Str 3 & Carajás & IREM 293-B /IAC 81-176 \\
B & Zenith & Confiança & IAC 164/IRAT 216 \\
C & NP-125 & Maravilha & TOX1010-49-1/IRAT121// (COL1xM312A \\
D & Usen & Primavera & IRAT10/LS85-158 \\
E & Dular & Progresso & (COL.1x M312A)IRAT124//RHS107-2-1-2TB-1 JM \\
F & Kanto & Caiapó & IRAT13/B.CAMPO//CNA $104 /$ PEROLA \\
G & Sha-tiao-tsao & IAC-47 & IAC 1246/IAC 1391 \\
H & Caloro & IAC-201 & IAC 165/LABELLE \\
\hline
\end{tabular}

${ }^{1}$ The isolates which produce resistant reaction on all eight differentials pertain to the pathotype group I. 
Pathotype diversity of Pyricularia grisea from improved upland rice cultivars...

TABLE 2 - Pathotypes of Pyricularia grisea determined based on standard international differentials, additional set of Brazilian upland rice (Oryza sativa) cultivars and virulence spectrum

\begin{tabular}{|c|c|c|c|c|c|c|c|c|c|}
\hline Cultivar ${ }^{1}$ & Isolate $^{2}$ & $I P^{3}$ & $\mathrm{BP}^{4}$ & $C V^{5}$ & Cultivar & Isolate & IP & BP & $\mathrm{CV}$ \\
\hline \multirow[t]{4}{*}{ Carisma } & Py2294-00 & IB-41 & BB-21 & 0.65 & Progresso & Py2396-00 & IB-33 & BB-41 & 0.75 \\
\hline & Рy2288-00 & IB-1 & BB-29 & 0.65 & & Py2390-00 & IB-41 & BB-21 & 0.65 \\
\hline & Py1983-99 & IB-9 & BB-29 & 0.71 & & Py1579-98 & IB-1 & BB-41 & 0.62 \\
\hline & Py1981-99 & IB45 & BA-21 & 0.56 & & Py1577-98 & IB-1 & BB-61 & 0.62 \\
\hline \multirow[t]{7}{*}{ Maravilha } & Py2436-00 & IB-41 & BB-21 & 0.68 & & Py1365-97 & IB-9 & BB-29 & 0.62 \\
\hline & Рy2433-00 & IB-1 & BB-21 & 0.75 & & Py964-96 & IB-9 & BB-61 & 0.56 \\
\hline & Py2004-99 & IB-9 & BB-21 & 0.68 & & Py962-96 & IB-1 & BB-21 & 0.68 \\
\hline & Py2001-99 & IB-9 & BB-45 & 0.62 & IAC-47 & Py $2254-00$ & IB-41 & BB-21 & 0.71 \\
\hline & Py1598-98 & IB-41 & BB-21 & 0.62 & & Py $2253-00$ & IB-9 & BB-21 & 0.68 \\
\hline & Py1387-97 & IB-9 & BB-29 & 0.59 & & Py1980-99 & IB-9 & BB-41 & 0.62 \\
\hline & Py1389-97 & IB-9 & BB-49 & 0.68 & & Py1593-98 & IB-41 & BB-21 & 0.65 \\
\hline \multirow[t]{6}{*}{ IAC-201 } & Py2248-00 & ID-9 & BD-16 & 0.31 & & Py1347-97 & IB-9 & BB-21 & 0.71 \\
\hline & Рy2249-00 & IB-9 & BB-41 & 0.71 & & Рy723-96 & IB-9 & BA-21 & 0.71 \\
\hline & Py1355-97 & IB-1 & BB-41 & 0.68 & Confiança & Py2362-00 & IG-1 & BI-1 & 0.12 \\
\hline & Рy948-96 & IB-9 & BB-57 & 0.59 & & Рy2356-00 & IB-9 & BB-41 & 0.62 \\
\hline & Рy940-96 & IB-9 & BB-61 & 0.59 & & Рy $1322-97$ & IB-45 & BB-21 & 0.65 \\
\hline & Py733-96 & IB-9 & BB-25 & 0.75 & & Py1317-97 & IB-9 & BB-13 & 0.53 \\
\hline \multirow[t]{7}{*}{ Rio Paranaíba } & Py2407-00 & IB-9 & BB-41 & 0.56 & & Py1311-97 & IB-41 & BB-41 & 0.53 \\
\hline & Py2403-00 & IB-9 & BD-9 & 0.59 & Carajás & Py2309-00 & IB-9 & BA-29 & 0.59 \\
\hline & Py2012-99 & IB-9 & BC-1 & 0.59 & & Py $2307-00$ & IB-9 & BA-29 & 0.65 \\
\hline & Py2010-99 & IB-9 & BB-41 & 0.62 & & Py2000-99 & IB-1 & BB-13 & 0.62 \\
\hline & Py $1589-98$ & IB-9 & BC-49 & 0.65 & & Py1997-97 & IB-37 & BA-125 & 0.62 \\
\hline & Py1276-97 & IB-9 & BB-41 & 0.62 & & Py1421-97 & IB-45 & BA-61 & 0.50 \\
\hline & Py1271-97 & IB-9 & BB-41 & 0.59 & & Py1415-97 & IB-45 & BA-53 & 0.65 \\
\hline \multirow[t]{7}{*}{ Caiapó } & Py2347-00 & IB-9 & BB-33 & 0.71 & Guarani & Py2425-00 & IB-41 & BB-21 & 0.68 \\
\hline & Py2345-00 & IB-1 & BB-9 & 0.81 & & Py $2422-00$ & IB-1 & BB-29 & 0.53 \\
\hline & Py1995-99 & IB-9 & BB-41 & 0.62 & & Py1971-99 & IB-1 & BD-9 & 0.50 \\
\hline & Py1991-99 & IB-1 & BB-41 & 0.68 & & Py1967-99 & IB-1 & BB-61 & 0.68 \\
\hline & Py1596-98 & IB-9 & BD-9 & 0.62 & & Py1586-98 & IB-1 & BB-41 & 0.65 \\
\hline & Py1594-97 & IB-9 & BB-1 & 0.75 & & Py1581-98 & IB-9 & BD-9 & 0.68 \\
\hline & Py1402-97 & IB-9 & BG-1 & 0.59 & & Py1393-97 & IB-9 & BA-9 & 0.71 \\
\hline \multirow[t]{5}{*}{ Primavera } & Py2376-00 & IC-25 & BD-16 & 0.25 & Araguaia & Рy2265-00 & IB-1 & BB-13 & 0.78 \\
\hline & Py2008-99 & IC-9 & BD-16 & 0.21 & & Py $2267-00$ & IB-9 & BA-29 & 0.71 \\
\hline & Py2007-99 & IC-1 & BD-16 & 0.37 & & Py $1359-97$ & IB-9 & BG-1 & 0.56 \\
\hline & Py1303-97 & IC-9 & BD-16 & 0.37 & & Py $1363-97$ & IB-9 & BB-45 & 0.59 \\
\hline & Py1300-97 & IB-9 & BB-41 & 0.59 & & Py646-96 & IB-9 & BF-1 & 0.56 \\
\hline \multirow[t]{7}{*}{ Canastra } & Py2323-00 & IB-9 & BB-21 & 0.71 & & Py651-96 & IB-9 & BG-1 & 0.53 \\
\hline & Py2329-00 & IB-41 & BB-21 & 0.68 & Bonança & Py2453-00 & IB-9 & BB-21 & 0.71 \\
\hline & Py1989-99 & IB-9 & BB-21 & 0.71 & & Py2449-00 & IB-33 & BB-21 & 0.75 \\
\hline & Py1988-99 & IB-9 & BB-21 & 0.68 & & Py1975-99 & IB-9 & BB-21 & 0.71 \\
\hline & Py1375-97 & IB-9 & BC-29 & 0.62 & & Py1977-99 & IB-9 & BB-21 & 0.75 \\
\hline & Py1379-97 & IB-9 & BB-21 & 0.71 & & Py $1978-99$ & IB-9 & BB-21 & 0.62 \\
\hline & Py1382-97 & IB-41 & BB-21 & 0.65 & & & & & \\
\hline
\end{tabular}

${ }^{1}$ Cultivar from which the isolate was collected $;{ }^{2}$ Accession number of $P$. grisea culture collection of Embrapa Rice $\&$ Beans, last two digits indicate the year of collection; ${ }^{3}$ International pathotype; ${ }^{4}$ Brazilian pathotype; ${ }^{5}$ Coeficient of virulence was calculated as the proportion of the total number of compatible (susceptible) reactions in relation to 32 genotypes.

the isolate collected from 'Primavera' has to be designated as IB-9/BD-17. These results are in accordance with those obtained in other countries, where the standard international set does not permit identification of all pathotype diversity that occurs in several rice growing regions (Ou, 1980; Bonman et al., 1986; Correa-Victoria \& Zeigler, 1993).

Distinct differences in virulence pattern of the isolates on 32 genotypes were observed (Table 2). The coefficient of virulence ranged from 0.12 for the pathotype IG-1/BI- 1 from 'Confiança' to 0.81 for the pathotype IB-1/BB-9 from 'Caiapó'. The cultivar 'Primavera' showed low coefficients of virulence varying from 0.21 to 0.59 .

The virulence pattern of 14 different isolates of pathotype IB-1 on Brazilian rice differentials is presented in Table 3. The eight international differentials showed one reaction pattern i.e. the isolates induced resistant reaction on 'Raminad Str 3' and susceptible reaction on all other differentials and hence was classified as pathotype IB-1. When the Brazilian commercial cultivars were utilized as differentials they could be further divided into eight pathotypes: BB-41, BB-13, BB-21, BB-9, BB-29, BB-61, BD9 and BG-1 (Table 3). Even though the four isolates of 
TABLE 3 - Virulence pattern of isolates classified as pathotype IB-1 of Pyricularia grisea on Brazilian rice (Oryza sativa) differentials

\begin{tabular}{|c|c|c|c|c|c|c|c|c|c|}
\hline Isolate $^{1}$ & $\begin{array}{c}\mathbf{A} \\
\text { Carajás }\end{array}$ & $\begin{array}{c}\text { B } \\
\text { Confiança }\end{array}$ & $\begin{array}{c}\text { C } \\
\text { Maravilha }\end{array}$ & $\begin{array}{c}\text { D } \\
\text { Primavera }\end{array}$ & $\begin{array}{c}E \\
\text { Progresso }\end{array}$ & $\begin{array}{c}\mathbf{F} \\
\text { Caiapó }\end{array}$ & $\underset{\text { IAC }-47}{G}$ & $\begin{array}{c}\text { H } \\
\text { IAC-201 }\end{array}$ & Pathotype $^{3}$ \\
\hline Py2433-00 & $\mathrm{R}^{2}$ & $\mathrm{~S}^{2}$ & S & $\mathrm{R}$ & S & $\mathrm{R}$ & S & S & BB-21 \\
\hline Рy2345-00 & $\mathrm{R}$ & $\mathrm{S}$ & S & S & $\mathrm{R}$ & S & S & S & BB-9 \\
\hline Py1991-99 & $\mathrm{R}$ & S & $\mathrm{R}$ & S & $\mathrm{R}$ & S & S & S & BB-41 \\
\hline Рy2265-00 & $\mathrm{R}$ & S & S & $\mathrm{S}$ & $\mathrm{R}$ & $\mathrm{R}$ & S & S & BB-13 \\
\hline Py1967-99 & $\mathrm{R}$ & S & $\mathrm{R}$ & $\mathrm{R}$ & $\mathrm{R}$ & $\mathrm{R}$ & S & S & BB-61 \\
\hline Py2288-00 & $\mathrm{R}$ & S & S & $\mathrm{R}$ & $\mathrm{R}$ & $\mathrm{R}$ & S & S & BB-29 \\
\hline Py1355-97 & $\mathrm{R}$ & S & $\mathrm{R}$ & $\mathrm{S}$ & $\mathrm{R}$ & S & S & S & BB-41 \\
\hline Py1579-98 & $\mathrm{R}$ & S & $\mathrm{R}$ & $\mathrm{S}$ & $\mathrm{R}$ & S & S & S & BB-41 \\
\hline Py1577-98 & $\mathrm{R}$ & S & $\mathrm{R}$ & $\mathrm{R}$ & $\mathrm{R}$ & $\mathrm{R}$ & S & S & BB-61 \\
\hline Рy962-96 & $\mathrm{R}$ & S & S & $\mathrm{R}$ & $\mathrm{R}$ & $\mathrm{R}$ & S & S & BB-29 \\
\hline Py1971-99 & $\mathrm{R}$ & $\mathrm{R}$ & $\mathrm{R}$ & S & $\mathrm{R}$ & $\mathrm{S}$ & S & S & BD-9 \\
\hline Py1359-97 & $\mathrm{R}$ & $\mathrm{R}$ & $\mathrm{R}$ & $\mathrm{R}$ & $\mathrm{R}$ & $\mathrm{R}$ & S & S & BG-1 \\
\hline Рy2000-99 & $\mathrm{R}$ & $\mathrm{S}$ & S & S & $\mathrm{R}$ & $\mathrm{R}$ & S & S & BB-13 \\
\hline Py1586-98 & $\mathrm{R}$ & $\mathrm{S}$ & $\mathrm{R}$ & S & $\mathrm{R}$ & $\mathrm{S}$ & $\mathrm{S}$ & $\mathrm{S}$ & BB-41 \\
\hline
\end{tabular}

${ }^{1}$ Accession number of $P$. grisea culture collection of Embrapa Rice \& Beans, last two digits indicate the year of collection; ${ }^{2} \mathrm{R}=$ resistant reaction; $\mathrm{S}=$ susceptible reaction; ${ }^{3}$ Pathotypes were identified using eight commercial upland rice cultivars as additional differentials

pathotype BB-41 were recovered from four different cultivars, (Py 1991-99 from 'Caiapó'; Py 1355-97 from 'IAC-201'; Py $1579-98$ from 'Progresso'; Py 1586-98 from 'Guarani') in different years, they showed similar virulence pattern. They exhibited resistant reaction on 'Carajás', 'Maravilha' and 'Progresso' and susceptible reaction on the other five differentials and thus classified as BB-41.

Both virulent and avirulent isolates were found in the population of $P$. grisea to the known genes in NIL's. Of 85 isolates, 82 and 79 were virulent for genes $P i-3$ and $P i-4 a$, respectively. These results suggest that the virulence on $P i-3$ and $P i-4$ pre-existed abundantly in populations of $P$. grisea even though these genes have never been utilized in upland rice breeding. The virulence frequencies were relatively lower in descending order on $P i-4 b, P i-2$, and $P i-1$. The host from which they were collected seems to condition the virulence pattern. For example, six of the seven isolates from 'Maravilha' were virulent to $P i-2$ and avirulent to $P i-1$. On the other hand, four of the six isolates originated from 'IAC201 ' were virulent to $P i-1$ and avirulent to $P i-2$.

Cross inoculations of $P$. grisea isolates on newly released cultivars 'Primavera', 'Maravilha', 'Bonança' and 'Carisma', from which they were collected, exhibited differential interaction between isolates and cultivars (Table 4). The five isolates, which were virulent to 'Primavera', were avirulent to 'Maravilha' whereas of the seven isolates of 'Maravilha' six were avirulent to 'Primavera'. The pathotype IB9/BB45 from 'Maravilha' was not virulent to 'Maravilha', but virulent to 'Primavera' (Table 4). Studies conducted in Philippines and Colombia with widely prevalent isolates of P. grisea also showed that some isolates were not found to be virulent to the cultivar of their origin. This was attributed to variation in virulence pattern of conidia produced in culture
TABLE 4 - Pathotype x cultivar interaction of Pyricularia grisea in relation to leaf blast reaction in inoculations tests

\begin{tabular}{|c|c|c|c|c|}
\hline \multirow{2}{*}{ Pathotype $^{1}$} & \multicolumn{4}{|c|}{ Cultivar } \\
\hline & Primavera & Maravilha & Bonança & Carisma \\
\hline \multicolumn{5}{|c|}{ 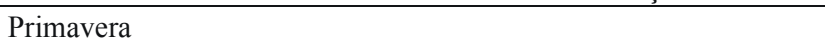 } \\
\hline IC-25/BD-16 & $9^{2}$ & 0 & 0 & 0 \\
\hline IC-9/BD-16 & 7 & 0 & 0 & 0 \\
\hline IC-1/BD-16 & 9 & 0 & 0 & 0 \\
\hline IC-9/BD-16 & 4 & 0 & 0 & 0 \\
\hline IB-9/BB-41 & 5 & 0 & 0 & 0 \\
\hline \multicolumn{5}{|l|}{ Maravilha } \\
\hline IB-41/BB-21 & 0 & 7 & 7 & 7 \\
\hline IB-1/BB-21 & 0 & 5 & 7 & 7 \\
\hline IB-9/BB-21 & 3 & 7 & 7 & 7 \\
\hline IB-9/BB-45 & 4 & 3 & 0 & 4 \\
\hline IB-41/BB-21 & 0 & 7 & 7 & 7 \\
\hline IB-9/BB-29 & 0 & 7 & 0 & 7 \\
\hline IB-9/BB-49 & 0 & 5 & 4 & 7 \\
\hline \multicolumn{5}{|l|}{ Bonança } \\
\hline IB-9/BB-21 & 0 & 9 & 7 & 9 \\
\hline IB-33/BB-21 & 0 & 7 & 7 & 7 \\
\hline IB-9/BB-21 & 0 & 7 & 5 & 4 \\
\hline IB-9/BB-21 & 0 & 7 & 5 & 7 \\
\hline IB-9/BB-21 & 0 & 4 & 5 & 7 \\
\hline \multicolumn{5}{|l|}{ Carisma } \\
\hline IB-41/BB-21 & 0 & 5 & 5 & 5 \\
\hline IB-1/BB-29 & 0 & 5 & 0 & 7 \\
\hline IB-9/BB-29 & 0 & 5 & 5 & 7 \\
\hline IB-45/BA-21 & 0 & 7 & 0 & 7 \\
\hline
\end{tabular}

International and Brazilian pathotypes of $P$. grisea were identified from isolates collected from commercial rice cultivars indicated in the column.

${ }^{2}$ Disease scores 0 to 3 and 4 to 9 correspond to resistant and susceptible reactions, respectively. 
Pathotype diversity of Pyricularia grisea from improved upland rice cultivars...

media and the resistance spectrum of the cultivar (Ou, 1980; Correa-Victoria \& Zeigler, 1993). The isolates from 'Primavera' were virulent to 'Primavera' and avirulent to 'Bonança' and vice versa. The isolates of 'Carisma' showed differences in their reaction on 'Bonança'. This indicates that the international and the Brazilian pathotypes may not give required information in relation to cultivar specific isolates. Pathotype may not necessarily be the appropriate phenotypic unit for breeding purpose because 71 distinct virulence patterns were observed on the 21 cultivars tested (Zeigler et al., 1995). The isolate cultivar interaction could be more useful for incorporating resistance genes against a specific isolate pertaining to a given pathotype. The advantages of pathotype analysis are to broadly group the pathogen population into a reduced number of units. For example, the 85 isolates in this study could be grouped into 11 international or 21 Brazilian pathotypes.

Individual differences in phenotypic virulence are common and the virulence pattern of the $P$. grisea in test plots must be monitored constantly. Virulence in the field also preexists for genes that have never been utilized but in low frequencies. The sample of isolates collected over a period of five years in this study showed variation between individuals with distinct differences in reaction on commercial rice cultivars. Some of the Brazilian pathotypes could be utilized for incorporating resistance genes in susceptible cultivars improved for grain quality by conventional breeding methods.

\section{LITERATURE CITED}

AMARAL, R.E.M., SOUZA, D.M., MALAVOLTA, U.M.A. \& ISSA, E. Raças fisiológicas de Pyricularia grisea Cav. no Estado de São Paulo. O Biológico 45:205-208. 1979.

ATKINS, J.G., ROBERT, A.L., ADAAIR, C.R., GOTO, K., KOZAKA, T., YANAGIDA, R., YAMADA, M. \& MATSUMOTO, S. An international set of rice varieties for differentiating races of Pyricularia oryzae. Phytopathology 57:297-301. 1967.

BEDENDO, I.P., RIBEIRO, A.S. \& CARDOSO, C.N. Variabilidade do fungo de Pyricularia oryzae, agente causal da brusone no arroz. Summa Phytopathologica 5:106-109. 1979.

BONMAN, J.M., DE DIOS, V.T.I., \& KHIN, M.M. Physiologic specialization of Pyricularia oryzae in the Philippines. Plant Disease 70:767-769. 1986.
CORREA-VICTORIA, F.J. \& ZEIGLER, R.S. Pathogenic variability in Pyricularia grisea at a rice blast "hot-spot" breeding site in Eastern Colombia. Plant Disease 77:1029-1035. 1993.

FILIPPI, M.C., PRABHU, A.S. \& LEVY, E.M. Differential compatibility of Pyricularia grisea isolates with some Brazilian irrigated rice cultivars. Fitopatologia Brasileira 24:447-450. 1999.

INTERNATIONAL RICE RESEARCH INSTITUTE. Standard evaluation system for rice. International rice testing program. $3^{\text {rd }}$ ed. Los Banos. International Rice Research Institute. 1988.

LATTERELL, F.M., TULLIS, E.C., OTTEN, R.J. \& GUBERNICK, A. Physiologic races of Pyricularia oryzae. Phytopathology 44:495-496. 1954 (Abstract).

LEVY, M., CORREA, F.J., ZEIGLER, R.S., XU, S. \& HAMER, J.E. Genetic diversity of the rice blast fungus in a disease nursery in Colombia. Phytopathology 83:1427-1433. 1993.

LING, K.C. \& OU, S.H. Standardization of the international race numbers of Pyricularia oryzae. Phytopathology 59:339-342. 1969.

MACKILL, D.J. \& BONMAN, J.M. Inheritance of blast resistance in near-isogenic lines of rice. Phytopathology 83:746-749. 1992.

MALAVOLTA,V.M.A. \& SOUZA, T.M.W. Variabilidade de Pyricularia oryzae no Estado de São Paulo. Summa Phytopathologica 18:287-290.1992.

OU, S.H. Pathogen variability and host resistance of the rice blast fungus, Pyricularia oryzae Cav. Annual Review of Phytopathology 18:167-187. 1980.

PRABHU, A.S. \& FILIPPI, M.C. As raças fisiológicas de Pyricularia oryzae virulentas nas cultivares melhoradas de arroz de sequeiro. Fitopatologia Brasileira 14:140. 1989. (Resumo).

RIBEIRO, A S. Prevalência de raças de Pyricularia oryzae Cav. No Rio Grande de Sul. Pesquisa Agropecuária Brasileira 15:175182. 1980 .

RIBEIRO, A.S. \& TERRES, A.N.L.S. Variabilidade do fungo Pyricularia oryzae e sua relação com cultivares resistentes à brusone. Fitopatologia Brasileira 12:316-321. 1987.

URASHIMA, A.S. \& ISOGAWA, Y. Identification of races of Pyricularia oryzae causing blast disease in variety IAC 4440 in Paraíba Valley-SP. Summa Phytopathologica 16:243-247. 1990.

YAMADA, M., KIYOSAWA, S., YAMAGUCHI, T., HIRANO, T., KOBAYASHI, K. \& WATANABI, S. Proposal for a new method for differentiating races of Pyricularia oryzae Cavra in Japan. Annual. Phytopathological Society of Japan. 42:216-219. 1976.

ZEIGLER, R.S., CUOC, L.X., SCOTT, R.P., BERNARDO, M.A., CHEN, D.H., VALENT, B. \& NELSON, R.J. The relationship between lineage and virulence in Pyricularia grisea in the Philippines. Phytopathology 85:443-451. 1995. 